UDK 577.1 : 61

ISSN 1452-8258

J Med Biochem 39: 481-487, 2020

\title{
INFLAMMATORY MARKERS IN END-STAGE RENAL DISEASE PATIENTS ON HAEMODIALYSIS
}

\author{
INFLAMATORNI MARKERI U POSLEDNJEM STADIJUMU \\ RENALNOG OBOLJENJA U PACIJENATA NA HEMODIJALIZI \\ Phebe Lotfy Abdel-Messeih ${ }^{1}$, Manal Mohamed Alkady ${ }^{1}$,
Neveen Mostafa Nosseir ${ }^{1}$, Mohamed Said Tawfik \\ ${ }^{1}$ Clinical Pathology Unit, Health Radiation Research Department, National Centers for Radiation \\ Research and Technology (Ncrrt), Egyptian Atomic Energy Authority (Eaea) \\ ${ }^{2}$ Head of Internal Medicine unit, Health Radiation Research Department, National Centers for Radiation \\ Research and Technology (Ncrrt), Egyptian Atomic Energy Authority (Aea), Cairo, Egypt
}

\begin{abstract}
Summary
Background: CXC chemokine ligand 16 (CXCL16) is an inflammatory chemokine that mediates renal infiltration of macrophages and activated T cells.

Aim: To investigate serum levels of CXCL16 in patients undergoing hemodialysis and their correlation with other inflammatory markers such as C-reactive protein (CRP) and intact parathyroid hormone (iPTH).

Methods: The study included 40 hemodialysis patients (22 males) and 40 age and gender-matched controls (24 males). Fasting blood sugar (FBS), urea, creatinine, calcium and inorganic phosphorous were assayed in participants using routine methods, glycosylated hemoglobin ( $\mathrm{HbA} 1 \mathrm{c})$ by quantitative chromatographic spectrophotometry, iPTH by chemiluminescent microparticle immunoassay, CRP by nephelometry and CXCL16 by ELISA technique.

Results: Serum CXCL16, CRP, PTH, FBS, HbA1c, phosphorus, urea, and creatinine levels were significantly higher in hemodialysis patients compared to controls $(p<0.00001)$. No statistically significant differences were observed between patients and controls for calcium. Serum CXCL16 levels correlated positively with CRP $(r=0.956$, $p<0.00001)$ and $\mathrm{iPTH}(r=-0.403, p<0.001)$. Hemodialysis patients (diabetics or hypertensives) had significantly higher CXCL16 levels compared to non-diabetics or non-hypertensives.
\end{abstract}

\section{Kratak sadržaj}

Uvod: CXC hemokin ligand 16 (CXCL16) je infalamatorni hemokin koji posreduje u bubrežnoj infiltraciji makrofaga i aktivira T ćelije.

Cilj: Svrha ovog rada je bila da se ispitaju nivoi serumskog CXCL16 u pacijenata koji su bili na hemodijalizi i njihova korelacija sa drugim inflamatornim markerima kao što su Creaktivni protein (CRP) i intaktni paratireoidni hormon (iPTH). Metode: Izučavanje je obuhvatilo 40 pacijenata na hemodijalizi (22 muškarca) i kontrolnu grupu starosti 40 godina (24 muškarca). Glukoza na tašte (FBS), ureja, kreatinin, kalcijum i neorganski fosfat su kod ispitanika određivani rutinskim metodama, glikozilirani hemoglobin (HbA1c) primenom kvantitativne hromatografske spektrometrije, iPTH hemiluminiscentnim imunoodređivanjem, CRP nefelometrijski i CXCL16 primenom ELISA tehnike.

Rezultati: Nivoi CXCL16, CRP, iPTH, FBS, ureje i kreatinina su bili značajno viši kod pacijenata na hemodijalizi u poređenju sa kontrolnom grupom ( $p<0,00001)$. Nisu nađene statistički značajne razlike između pacijenata i kontrolne grupe za vrednosti kalcijuma, fosfora i HbA1c. Nivoi CXC16 bili su u pozitivnoj korelaciji sa vrednostima CRP $(r=0,956$, $p<0,00001)$ i iPTH $(r=-0,403, p<0,001)$. Pacijenti na hemodijalizi (dijabetičari ili hipertenzivni) imali su značajno više nivoe u poređenju sa ne-dijabetičarima ili sa pacijentima koji nisu bili hipertenzivni.

Address for correspondence:

Mohamed Said Tawfik

Health Radiation Research Department,

National Centers for Radiation Research and Technology (NCRRT),

Egyptian Atomic Energy Authority (AEA), Cairo, Egypt

e-mail:mstewfik@hotmail.com,mstewfik@yahoo.com

mmstewfik@hotmail.com.

Address: 6 Ahmed Elhofy Street, Agouza, Giza, Egypt.

P.O. Box/Postal Code: 12411. 
Conclusions: High levels of serum CXCL16, CRP and iPTH reflect the inflammatory status of hemodialysis patients and help avoid complications. Serum CXCL16 could be used as a biomarker together with CRP in these patients.

Keywords: CXCL16, iPTH, CRP, ESRD

\section{Introduction}

Chronic kidney disease (CKD) is recognized as a syndrome that carries a high risk of morbidity and mortality. The consequent kidney tissue damage may end up with the patient depending on lifelong hemodialysis (1). The chief causes of CKD are diabetes mellitus and hypertension, which are involved in up to two-thirds of cases (2). The progression to endstage renal disease (ESRD) is defined by an estimated glomerular filtration rate (eGFR) less than $15 \mathrm{~mL} / \mathrm{min}$ per $1.73 \mathrm{~m}^{2}$ and undergoing renal replacement therapy or dialysis treatment for survival (2). Chronic kidney disease is the principal and one of the quickest growing causes of mortality all over the globe (3).

Cardiovascular disease (CVD) is on the list of the leading causes of mortality in CKD patients (4). Nevertheless, the exact etiology linking CKD with CVD remains poorly understood and consequently, therapy nowadays is regarded as being unsatisfactory. A chronic low-grade systemic inflammation in addition to dyslipidemias are believed to play a major role (5).

Chemokine ligand-16 (CXCL16) is a small cytokine categorized as being a part of the CXC chemokine family. It combines scavenger receptor functions with properties of an inflammatory chemokine $(5,6)$. It exists in a transmembrane as well as a soluble form. The transmembrane form is comprised of a chemokine domain, a mucin-like stalk, a transmembrane domain, as well as a cytoplasmic tail. The soluble form results from cleavage at the cell surface and is composed of an extracellular stalk and chemokine domain (7). The transmembrane form functions as an adhesion molecule for CXCL16 expressing cells and as a scavenger receptor for pathogenic oxidized low-density lipoproteins (oxLDL). The soluble form is regarded as a chemoattractant that enhances the migration of CXC chemokine receptor type 6 (CXCR6) expressing cells including $T$ cells, monocytes, and myeloid fibroblasts (8). Transmembrane CXCL16 has been found to be present on glomerular and tubular cells during renal injury (9).

Approximately 30 to $50 \%$ of CKD cases have been found to have noticeably raised levels of serum inflammatory biomarkers including C-reactive protein (CRP) and interleukin-6 (IL6) (10). The etiology of inflammation in this case is multifaceted and involves patient-related causes, such as underlying disease, comorbidity, oxidative stress, infections, obesity, genetic or immunologic factors, or on the other hand,
Zaključak: Visoki nivoi serumskog CXCL16, CRP i iPTH odražavaju inflamatorni status pacijenata na hemodijalizi i pomažu izbegavanju komplikacija. Serumski CXCL16 može da se koristi kao biomarker zajedno sa CRP kod ovih pacijenata.

Ključne reči: CXCL16, iPTH, CRP, ESRD

hemodialysis-related factors, mainly concerning the dialysis membrane biocompatibility and dialysate quality (11).

Secondary hyperparathyroidism is known to be another cause of morbidity and mortality in patients with end stage renal disease (12). Growing evidence implies that higher levels of parathyroid hormone may be accompanied by low-grade inflammation but this association remains uncertain. Parathyroid hormone encourages interleukin-6 (IL-6) production by osteoclast and liver cells (13). Other studies showed elevated levels of $\mathrm{C}$-reactive protein (CRP), tumor necrosis factor- $\alpha$ and other inflammatory markers in hyperparathyroidism patients $(14,15)$.

The aim of the current study was to investigate serum levels of CXCL16 in patients undergoing hemodialysis and their correlation with other inflammatory markers such as highly sensitive $\mathrm{C}$-reactive protein (CRP) and uremic toxins as intact parathyroid hormone (iPTH).

\section{Materials and Methods}

The present study was performed on a selected group of 40 patients (22 males) with diagnosed end stage renal disease from those attending the hemodialysis unit of Cairo University hospitals in the period from October to December 2018. Their mean age was $47.6 \pm 13.4$. All underwent dialysis three times weekly during a period of four hours using synthetic membranes (Fresenius polysulfone UF 4.0; Fresenius Medical Care, Hamburg, Germany). All patients fulfilled the criteria of adequate dialysis ( $\mathrm{Kt} / \mathrm{V} \geq 1.2$ according to the Daugirdas II formula). All patients had either hypertension or diabetes mellitus or both. The study included 10 patients (25\%) with hypertension, 14 patients (35\%) with diabetes mellitus and 16 patients (40\%) with both hypertension and diabetes. Patients with acute infections, cancer, hepatic disease, heart failure and myocardial infarction were excluded from the study.

Blood samples were withdrawn from the arteriovenous fistula of hemodialyzed patients before starting the dialysis session. Informed consent was obtained from all participants in the study. This study followed the ethical standards of the national research committee given in the Declaration of Helsinki 1964, as revised in 2013. In addition, this study followed the ethical standards of the National Center for Radiation Research and Technology 
(NCRRT) Ethical Committee (Cairo) and this work was given the approval code $8 \mathrm{H} / 19$. The authors affirm that they have no conflict of interest. The control group comprised another group of 40 age and gender matched apparently healthy subjects (24 males). Their mean age was $45.4 \pm 15.6$. They attended their routine visits at the preventive health service clinic on the same day of patients' dialysis appointments. They were considered as healthy volunteers with normal complete blood count, fasting blood glucose, liver and kidney functions.

A detailed medical anamnesis was obtained from patients and controls, and a careful clinical examination was completed for them.

Blood samples were collected from all participants in suitable vacutainers. Sera and plasma were separated as the preferred schedule and kept at $-20{ }^{\circ} \mathrm{C}$ till assay time. Fasting blood sugar, urea, creatinine, calcium and inorganic phosphorous were measured using routine methods on Hitachi 971 instrument (Roche Diagnostics GmbH, D, 68298 Mannheim). glycosylated hemoglobin (HbA1c) was determined by quantitative chromatographic spectrophotometric determination using a kit provided by Biosystem reagents and instruments, Barcelona (Spain) (16). Highly sensitive C-reactive protein (CRP) was assayed by nephelometry using BN-Prospect system (Dade Behring, GmbH, Marburg, Germany) (17). Intact PTH (iPTH) levels were determined by intact PTH assay using chemiluminescent microparticle immunoassay on the ARCHITECT I system provided by ABBOTT Diagnostics Division, Biokit S.A. 08186 Barcelona, Spain (18). Serum CXCL16 levels were measured using a suitable ELISA kit purchased from Wuhan EIAAB Scientific Co., China according to the manufacturer's instructions.

\section{Statistical Analysis}

All data in this work was expressed as mean \pm standard deviation. Correlations between Serum CXCL16, CRP, PTH as well as other variables were evaluated by Pearson's Correlation test. Comparisons between the means of two groups were evaluated using Student's two tailed t-test. All statistical analysis was carried out using Statplus version 2 for Macintosh statistical software.

\section{Results}

The current study included a total of 40 patients on hemodialysis (30 patients had diabetes mellitus while 26 patients were hypertensive). Serum CXCL16, CRP, PTH, FBS, urea, and creatinine levels were statistically significantly higher in patients participating in the study compared to the controls $(p<0.0001)$. Glycosylated hemoglobin percentage (HbA1c) and phosphorus levels were also found to be significantly
Table I Basic clinical and biochemical data for the patients vs. controls.

\begin{tabular}{|c|c|c|c|}
\hline Parameter & $\begin{array}{l}\text { Controls } \\
(n=40)\end{array}$ & $\begin{array}{l}\text { Patients } \\
(n=40)\end{array}$ & P-value \\
\hline Age (years) & $45.4 \pm 15.60$ & $47.60 \pm 13.40$ & 1.50 \\
\hline $\begin{array}{l}\text { Sex ratio } \\
\text { (Male/Female) }\end{array}$ & $24 / 16$ & $22 / 18$ & N/A \\
\hline $\begin{array}{l}\text { CXC Chemokine } \\
\text { Ligand-16 } \\
(\mu \mathrm{g} / \mathrm{mL})\end{array}$ & $46.75 \pm 7.78$ & $162.95 \pm 89.7$ & $<0.0001$ \\
\hline $\begin{array}{l}\text { Parathormone } \\
(\mathrm{pg} / \mathrm{mL})\end{array}$ & $39.55 \pm 19.54$ & $293.35 \pm 234.1$ & $<0.0001$ \\
\hline $\begin{array}{l}\text { C-reactive } \\
\text { Protein }(\mu \mathrm{g} / \mathrm{mL})\end{array}$ & $3.80 \pm 3.14$ & $39.10 \pm 23.69$ & $<0.0001$ \\
\hline $\begin{array}{l}\text { Fasting glucose } \\
(\mathrm{mmol} / \mathrm{L})\end{array}$ & $4.93 \pm 0.38$ & $8.60 \pm 1.96$ & $<0.0001$ \\
\hline $\begin{array}{l}\text { Glycosylated } \\
\text { hemoglobin (\%) }\end{array}$ & $5.01 \pm 0.47$ & $5.93 \pm 0.94$ & $<0.0004$ \\
\hline $\begin{array}{l}\text { Creatinine } \\
(\mu \mathrm{mol} / \mathrm{L})\end{array}$ & $90.16 \pm 22.98$ & $617.9 \pm 155.58$ & $<0.0001$ \\
\hline Urea (mmol/L) & $9.62 \pm 2.22$ & $42.40 \pm 13.26$ & $<0.0001$ \\
\hline $\begin{array}{l}\text { Calcium } \\
(\mathrm{mmol} / \mathrm{L})\end{array}$ & $8.48 \pm 0.47$ & $8.79 \pm 0.61$ & $<0.08$ \\
\hline $\begin{array}{l}\text { Phosphorus } \\
\text { (mmol/L) }\end{array}$ & $3.46 \pm 0.46$ & $4.39 \pm 1.26$ & $<0.004$ \\
\hline
\end{tabular}

$\mathrm{N} / \mathrm{A}=$ Not Applicable. $\mathrm{P}<0.05=$ Significant $\mathrm{P}<0.01=$ Highly Significant

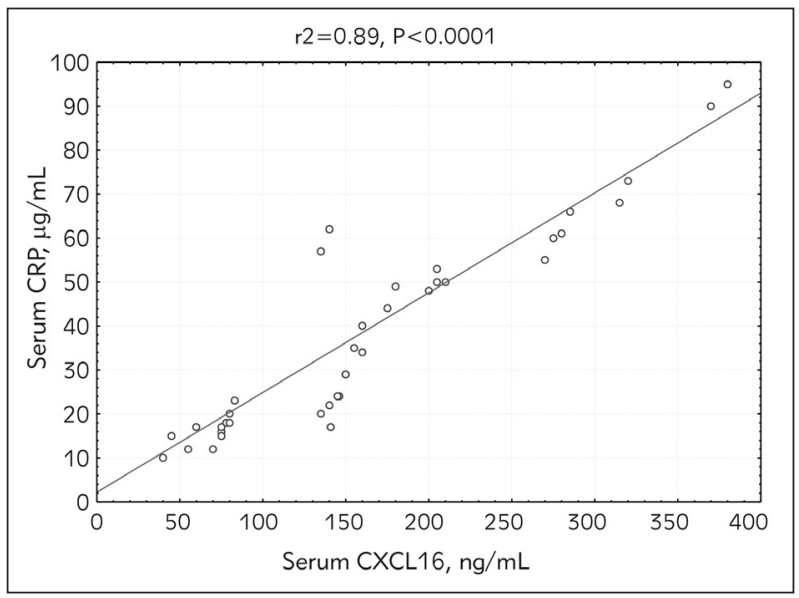

Figure 1 Correlation between CXC chemokine ligand 16 (CXCL-16) and C-reactive protein (CRP) in end stage renal disease (ESRD) patients on hemodialysis.

higher in hemodialysis patients compared to the controls $(p<0.0004)$. However, no statistically significant differences were observed in the cases compared to the controls as regards calcium levels. These findings are presented in Table / below. Serum CXCL16 levels correlated positively with CRP ( $r=0.956$, $\mathrm{p}<0.00001)$. Also, a highly significant positive correlation was detected between iPTH and CXCL16 ( $r=-$ 


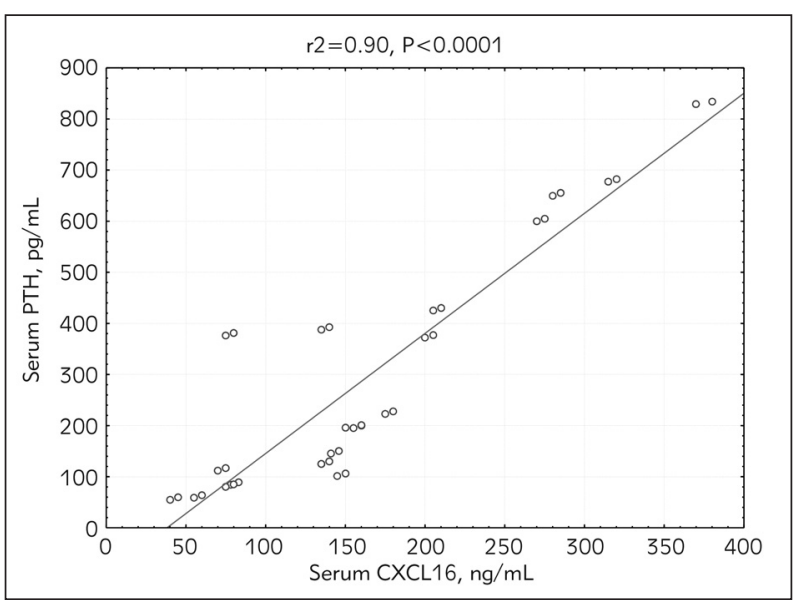

Figure 2 Correlation between CXC chemokine ligand 16 (CXCL16) and intact parathyroid hormone (iPTH) in end stage renal disease (ESRD) patients on hemodialysis.

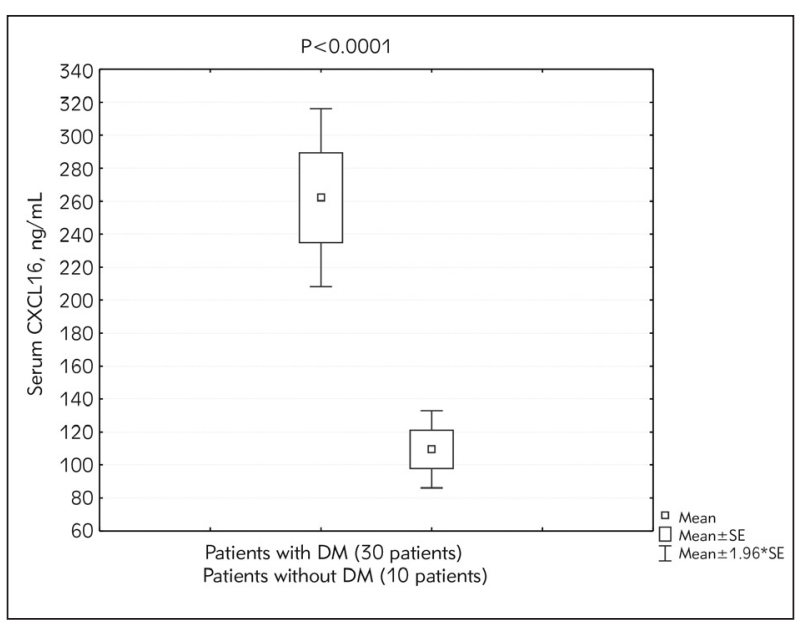

Figure 3 Serum CXC chemokine ligand 16 (CXCL16) in end stage renal disease (ESRD) patients on hemodialysis with and without diabetes mellitus (DM).

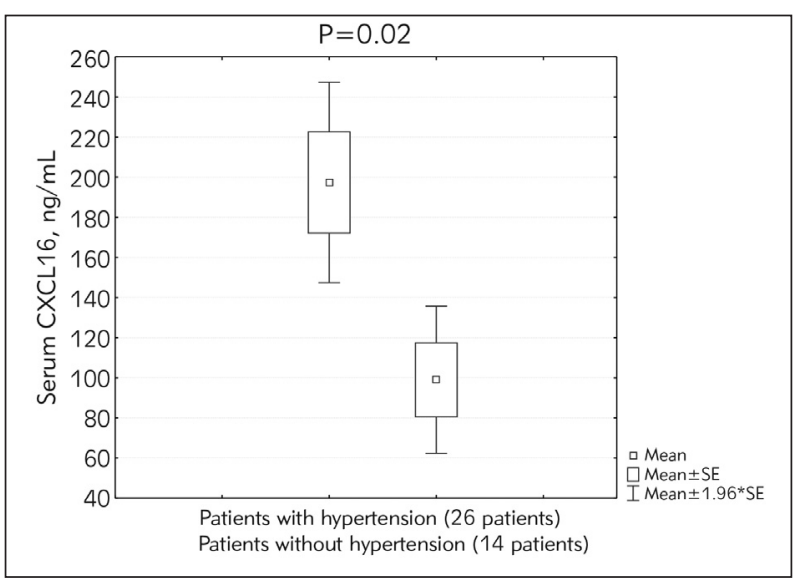

Figure 4 Serum CXC chemokine ligand 16 (CXCL16) in end stage renal disease (ESRD) patients on hemodialysis with and without hypertension.
0.403, p<0.001) (Figures 1 and 2). Diabetic and hypertensive hemodialysis patients demonstrated highly significant CXCL16 levels compared to those who were non-diabetic or non-hypertensive respectively (Figures 3 and 4).

\section{Discussion}

Patients on chronic hemodialysis are at a greater risk of morbidity and mortality that can not only be explained by traditional risk factors of atherosclerosis like diabetes, hypertension, dyslipidemia but also the other factors like inflammation (19). The causes of inflammation in hemodialysis patients are multifactorial. An inflammatory reaction may originate from several sites including graft, fistula, dialysis membrane and chronic infections (20).

In the current study, there were increased levels of serum CXCL16 and CRP observed in patients on hemodialysis compared to the controls demonstrating that dialysis treatment and uremia may cause hyperactivation of the immune system leading to an elevation of peripheral markers of immune activation mainly cytokines and chemokines. All alterations in innate immunity are understood to lead to an elevation of cytokines and inflammatory markers (21). Cytokines are known to be the chief controllers of host response to infection and inflammation and play a part in arterial disease and mortality in hemodialysis patients (22). Furthermore, proinflammatory cytokines stimulate the release and synthesis of acute phase proteins such as CRP from hepatocytes during inflammation (23).

Under normal baseline conditions, inflammation is unanimously regarded as a protective and physiological reaction to various harmful stimuli. Nonetheless, in chronic kidney disease (CKD), persistent systemic inflammation is accompanied by increased mortality due to cardiovascular disease (CVD) and infectious complications related to immune dysfunction (24). C-reactive protein seems to be connected to endothelial dysfunction and foam cell formation (25). Rising evidence has implied that there is an association between inflammation and cardiovascular (CV) risk. However, a precise underlying relationship cannot be identified.

Secondary hyperparathyroidism is one of the first disorders in mineral metabolism in patients on hemodialysis. The increase of parathormone (PTH) is caused by acidosis, resistance to calcitriol, decreased blood calcium due to the reduction of the active form of vitamin D (26). Parathormone is considered a uremic toxin which may inflict damage in multiple organs. Recently Cheng et al. (27) have shown that PTH levels have an impact on the symptoms and quality of life in dialysis patients with secondary hyperparathyroidism. Parathyroidectomy in these patients has been shown to improve their quality of life. 
Accumulating evidence suggests that higher PTH levels may be associated with low grade inflammation. The reason and effect association between PTH and inflammation remains uncertain.

In the present study, serum iPTH levels were significantly higher in dialysis patients compared to the controls. Moreover, a highly significant positive correlation was found between PTH and the inflammatory chemokine CXCL16. Also, CXCL16 levels were positively associated with CRP. Similar correlations were obtained by Elewa et al. (28) and Nazari et al. (29).

Our results pointed to an association between iPTH and inflammation. CRP is considered to be the most important marker of inflammation related to $\mathrm{CV}$ complications. Cheng et al. (27) found a significant positive correlation between PTH and CRP. Hu et al. (30) demonstrated for the first time that inflammation accelerated lipid accumulation in renal tubules and that tubular damage occurred via the upregulation of CXCL16 pathways and significantly accelerated renal failure. Furthermore, there is experimental evidence that CXCL16 may cause glomerular injury adding a further potential explanation to the clinical association observed between CXCL16, markers of inflammation such as CRP and uremic toxins such as PTH (26). The results verify that CXCL16 levels increase considerably in chronic renal disease and are in congruence with the results observed by Nazari et al. (29) who revealed that CXCL16 levels were 2.5 times higher in CKD subjects than healthy controls. Therefore, it is reasonable that chronic inflammation could have a close relationship to hemodialysis.

Unal et al. (31) documented that increased highly sensitive c-reactive protein (CRP) and PTH levels was associated with increased serum CXCL16 levels. This association was evidenced by multiple stepwise regression analysis of variables that were independently associated with serum levels of CXCL16 including decreased eGFR, diabetes mellitus, hypertension, increased CRP and PTH levels.

Results of the present study showed that hemodialysis patients with diabetes or hypertension had significantly higher CXCL16 levels compared to hemodialysis patients without diabetes or hypertension respectively. Comparable results were reported by Lin et al. (32) who found higher CXCL16 levels in
Chinese patients who were diabetic with CKD than those without diabetes mellitus. This could explain the increased incidence of coronary artery disease (CAD) in those patients and the close relationship between CAD and increased levels of CXCL16. Another explanation is that CXCL16 by itself could be a cause of insulin resistance. Even though CRP levels are generally increased in inflammatory diseases, it seems that serum CXCL16 may be a better biomarker than CRP in diabetic patients with CAD.

Lv et al. (33) found an increase in the levels of soluble CXCL16 in patients with metabolic syndrome and documented that CXCL16 was a proinflammatory factor that was associated with plaque formation. Also, Elewa et al. (28) documented higher CXCL16 levels in patients with prior CVD on top of CKD compared to those with CKD per se. Additionally, Nazari et al. (29) observed a similar significant difference between hemodialysis patients and hemodialysis patients with CVD. There are several limitations in this study. A larger sample size may be needed for more comprehensive investigations. Parameters of lipid and antioxidant status were overlooked and the study focused on the inflammatory markers and this is due to the fact that many studies stated that they are more important in hemodialysis patients than traditional risk factors. In addition, serum albumin, LDL and HDL cholesterol levels are known to decrease with inflammation.

\section{Conclusion}

In conclusion, patients on hemodialysis are at a greater danger of suffering an inflammatory reaction against factors originating from grafts, fistulae and dialysis membranes. These reactions are linked to increased levels of inflammatory markers such as CRP and cytokines such as CXCL16. CXCL16 could be used as an inflammatory biomarker together with CRP in hemodialysis patients. Hyperparathyroidism could be a condition related to the inflammatory status in hemodialysis patients.

\section{Conflict of interest statement}

The authors declare that they have no conflicts of interest in this work. 


\section{References}

1. National Kidney Foundation. KDOQI clinical practice guidelines for chronic kidney disease: evaluation, classification, and stratification. Am J Kidney Dis 2002; 39(2 suppl 1): S1-S266.

2. Grill AK, Brimble S. Approach to the detection and management of chronic kidney disease: What primary care providers need to know. Can Fam Physician 2018; 64(10): 728-35.

3. GBD 2013 Mortality and Causes of Death Collaborators. A systematic analysis for the Global Burden of Disease Study 2013. Lancet 2015; 385: 117-71.

4. Ortiz A, Covic A, Fliser D, Fouque D, Goldsmith D et al. Epidemiology, contributors to, and clinical trials of mortality risk in chronic kidney failure. Lancet 2014; 383: $1831-43$.

5. Izquierdo MC, Martin-Cleary C, Fernandez-Fernandez B, Elewa U, Sanchez-Niño MD et al. CXCL16 in kidney and cardiovascular injury. Cytokine Growth Factor Rev 2014; 25: 317-25.

6. Aslanian AM, Charo IF. Targeted disruption of the scavenger receptor and chemokine CXCL16 accelerates atherosclerosis. Circulation 2006; 114: 583-90.

7. Shimaoka T, Kume N, Minami M, Hayashida K, Kataoka $\mathrm{H}$ et al. Molecular cloning of a novel scavenger receptor for oxidized low-density lipoprotein, SR-PSOX, on macrophages. J Biol Chem 2000; 275: 40663-6.

8. Wu T, Xie C, Wang HW, Zhou XJ, Schwartz et al. Elevated urinary VCAM-1, P-selectin, soluble TNF receptor- 1 , and CXC chemokine ligand 16 in multiple murine lupus strains and human lupus nephritis. J Immunol 2007; 179: 7166-75.

9. Ležaić V. Serum and urinary biomarkers determination and their significance in diagnosis of kidney disease. J Med Biochem 2010; 29: 288-97.

10. Panichi V, Maggiore U, Taccola D, Migliori M, Rizza GM et al. Interleukin- 6 is a stronger predictor of total and cardiovascular mortality than C-reactive protein in dialytic patients. Nephrol Dial Transplant 2004; 19: 1154-60.

11. Jerin A, Mosa OF, Kališnik JM, Žibert J, Skitek M. Serum Klotho as a marker for early diagnosis of acute kidney injury after cardiac surgery. J Med Biochem 2020; 39: 133-9.

12. de Francisco AL. Secondary hyperparathyroidism: review of the disease and its treatment. Clin Ther 2004; 26(12): 1976-93.

13. Mitnick MA, Grey A, Masiukiewicz $U$ et al., "Parathyroid hormone induces hepatic production of bioactive interleukin- 6 and its soluble receptor, " American Journal of Physiology: Endocrinology and Metabolism, vol. 280, no. 3, pp. E405-E412, 2001.

14. Grey A, Mitnick MA, Shapses S, Ellison A, Gundberg C et al. Circulating levels of interleukin- 6 and tumor necrosis factor- are elevated in primary hyperparathyroidism and correlate with markers of bone resorption-a clinical research center study. Journal of Clinical Endocrinology and Metabolism, vol. 81, no. 10, pp. 3450-3454, 1996.
15. Emam AA, Mousa SG, Ahmed KY, Al- Azab AA. Inflammatory biomarkers in patients with asymptomatic primary hyperparathyroidism, Medical Principles and Practice 2012; 21: 249-53.

16. Roberts L, Jones TW, Fournier PA. Exercise training and glycemic control in adolescents with poorly controlled type 1 diabetes mellitus. J Pediatr Endocrinol Metab 2002; 15(5): 621-7.

17. Sproston NR, Ashworth JJ. Role of C-Reactive Protein at Sites of Inflammation and Infection. Front Immunol 2018; 9: 754.

18. Kritmetapak K, Pongchaiyakul C. Parathyroid Hormone Measurement in Chronic Kidney Disease: From Basics to Clinical Implications. Int J Nephrol 2019; 2019: 5496710. doi: 10.1155/2019/5496710.

19. Heidari B. C-reactive protein and other markers of inflammation in hemodialysis patients. Caspian J Intern Med 2013 Winter; 4(1): 611-6.

20. Nadeem M, Stephen L, Schubert C, Davids MR. Association between periodontitis and systemic inflammation in patients with end-stage renal disease. SADJ 2009; 64: 470-3.

21. Sardenberg C, Suassuna P, Andreoli MC, Watanabe R, Dalboni MA et al. Effects of uraemia and dialysis modality on polymorphonuclear cell apoptosis and function. Nephrol Dial Transplant 2006; 21(1): 160-5.

22. Dinarello CA. Proinflammatory cytokines. Chest 2000; 118(2): 503-8.

23. Baragetti I, El Essawy B, Fiorina P. Targeting Immunity in End-Stage Renal Disease. Am J Nephrol 2017; 45(4): 310-9.

24. Cobo G, Lindholm B, Stenvinkel P. 19. Chronic inflammation in end-stage renal disease and dialysis. Nephrol Dial Transplant 2018; 33(suppl_3): iii35-iii40. doi:10.1093/ndt/gfy175

25. Zimmermann O, Li K, Zaczkiewicz M, Graf M, Liu Z, Torzewski J. C-reactive protein i $1 \mathrm{n}$ human atherogenesis: facts and fiction. Mediators Inflamm.

26. Yuen NK, Ananthakrishnan S, Campbell MJ. Hyperparathyroidism of Renal Disease. Perm J 2016; 20(3): 15127.

27. Cheng SP, Lee JJ, Liu TP, Yang TL, Chen HH et al. Parathyroidectomy improves symptomatology and quality of life in patients with secondary hyperparathyroidism. Surgery 2014; 155(2): 320-8.

28. Elewa U, Sanchez-Niño MD, Mahillo-Fernández I, Martin-Cleary C, Belen Sanz A et al. Circulating CXCL16 in Diabetic Kidney Disease. Kidney Blood Press Res 2016; 41(5): 663-71.

29. Nazari AD, Sardoo AM, Fard ET, Khorramdelazad $H$, Hassanshahi G et al. Plasma CXCL16 Level is Associated with Cardiovascular Disease in Iranian Hemodialysis Patients. Biomed \& Pharmacol J 2017; 10(1): 01-07.

30. Hu ZB, Chen Y, Gong YX, Gao M, Zhang $Y$ et al. Activation of the CXCL16/CXCR6 Pathway by Inflammation Contributes to Atherosclerosis in Patients with 
End-stage Renal Disease. Int J Med Sci 2016 20; 13(11): 858-67.

31. Unal HU, Kurt YG, Gok M, Cetinkaya H, Karaman M et al. The Importance of Serum CXCL16 Levels in Patients with Grade III-V Chronic Kidney Disease. Turk Neph Dial Transpl 2014; 23 (3): 234-9.
32. Lin Z, Gong Q, Zhou Z, Zhang W, Liao S. et al. Increased plasma CXCL16 levels in patients with chronic kidney diseases. Eur J Clin Invest 2011; 41(8): 836-45.

33. Lv Y, Hou X, Ti Y, Bu P. Associations of CXCL16/CXCR6 with carotid atherosclerosis in patients with metabolic syndrome. Clin Nutr 2013; 32(5): 849-54.

Received: November 07, 2019

Accepted: January 07, 2020 